\title{
PRIKAZ TRENING SEMINARA ZA EUROPSKE DOKUMENTACIJSKE CENTRE, BRUXELLES, 22. - 23. STUDENOGA 2018.
} (TRAINING SEMINAR EUROPEAN DOCUMENTATION CENTRES, BRUSSELS, 22-23. 11. 2018)

Svake godine, u organizaciji Glavne uprave za komunikaciju Europske komisije (DG COMM - Directorate-General for Communication, European Commision) održava se trening seminar predstavnika europskih dokumentacijskih centara (EDC), koji djeluju u okviru informacijsko-komunikacijske mreže Europe Direct.

U Republici Hrvatskoj djeluje sedam centara, od ukupno 400 koliko ih ima diljem članica Europske unije. Kod nas su dokumentacijski centri uglavnom smješteni pri knjižnicama. Primarna je uloga tih centara promicanje i razvijanje studijskih i istraživačkih djelovanja u području europskih integracija, omogućavanje pristupa informacijama i izvorima o Europskoj uniji i njezinim politikama. Osim toga, dokumentacijski centri organiziraju tribine o Europskoj uniji, surađuju i s drugim europskim informacijskim službama i mrežama za prijenos informacija u okviru informacijsko-komunikacijskog djelovanja mreže Europe Direct.

Ovogodišnji trening-seminar održan je od 22. do 23. studenog u Bruxellesu u hotelu NH Brussels Bloom. Na seminaru je bilo nazočno stotinjak predstavnika EDC-a iz 24 zemlje Europske unije, uključujući i troje sudionika iz Republike Hrvatske: Ljiljana Siber s Pravnog fakulteta u Osijeku, Ivana Kežić Pucketić iz Nacionalne i sveučilišne knjižnice u Zagrebu te Darija Miočevića s Ekonomskog fakulteta u Splitu.

U uvodnom dijelu program predstavili su se moderatori John MacDonald i Sheona Dorson-King, a pozdravnu riječ održala je Sixtine Bouygues, zamjenica glavnog direktora Glavne uprave za komunikaciju Europske komisije.

Prvo izlaganje bilo je na temu Europski izbori, što se planira?, a održali su ga Sarah Sheil, voditeljica Odjela za strukturne politike u Službi Europskog parlamenta za istraživanja i Philipp Schulmeister, voditelj Odjela za praćenje javnog mnijenja Glavne uprave za komunikaciju Europskog parlamenta. Govorili su o aktivnostima koje su planirane za izbore 2019. godine te o mogućnostima za uključivanje EDC-a. Preporuka je da se EDC-i povežu s lokalnim

\footnotetext{
Ivana Kežić Pucketić, mag. bibl., Nacionalna i sveučilišna knjižnica u Zagrebu, Bratske zajednice 4, 10000 Zagreb, Republika Hrvatska. Adresa e-pošte: ivana.kezic@nsk.hr.

** Ljiljana Siber, viša knjižničarka, mag. bibl., mag. iur., Pravni fakultet Sveučilišta Josipa Jurja Strossmayera u Osijeku, Stjepana Radića 13,31000 Osijek, Republika Hrvatska.Adresa e-pošte:ljsiber@pravos.hr. ORCID:https://orcid.org/0000-0001-6865-755X.
} 
europskim dokumentacijskim informacijskim centrima i zajedničkim aktivnostima uključe u kampanju pod nazivom Ovaj put glasam.

Drugo izlaganje održao je Renaud Soufflot de Magny, asistent glavnog direktora Glavne uprave za komunikaciju Europskog parlamenta, o stanju Unije 2018. Osvrnuo se na govor o stanju Unije Jean-Claudea Junckera, predsjednika Europske komisije, u kojem je iznio svoje prioritete za predstojeću godinu te viziju daljnje izgradnje Unije.

Treće predavanje bilo je posvećeno Općoj uredbi o zaštiti podataka (GDPR), a predavačica je bila Isabelle Chatelier, djelatnica u Odjelu za zaštitu podataka Glavne uprave za pravosuđe i potrošače Europske komisije. Govorila je o novom dobu zaštite podataka u EU-u, prednostima izmjena iz 2018. te njihova utjecaja na rad EDC-ova.

Četvrto izlaganje održao je Edward Demicoli, voditelj Sektora komunikacija i medija Glavne uprave za migracije i unutarnje poslove Europske komisije. Gospodin Demicoli u svojemu se izlaganju posvetio tematiziranju važnosti alata, najboljih praksi, ali i izazovima s kojima se susrećemo kad je riječ o migracijama te pitanju azila.

Jedna od najzanimljivijih sesija bila je posvećena primjerima dobre prakse u radu europskih dokumentacijskih centara. Svoja iskustva u radu, suradnji s EDIC-ima, mjerodavnim ustanovama, zajednicom, kao i iskustva različitih događanja iznijeli su Eva Ramón, EDC Universidad Francisco de Vitoria iz Španjolske, Stefan Bezzina, EDC University of Malta, Katrin Lück, EDC Saarland University iz Njemačke i Georgia Christodoulou, EDC University of Nicosia s Cipra. Sva iznesena iskustva izvrsni su praktični primjeri i dobrom smjernicom za ostale sudionike kad je riječ o budućim projektima i djelovanjima. Moderator je bio Alessandro Giordani, voditelj Odjela Komunikacija s građanima Glavne uprave za komunikaciju Europske komisije.

U popodnevnom dijelu prvoga dana trening seminara središnjom temom bio je Ured za publikacije. Uvodno predavanje održao je Dietmar Braun, voditelj Odjela za odnose s dionicima Ureda za publikacije EU-a. Gospodin Braun iznio je osnovne planove za nadolazeću djelatnost Ureda.

Bo Sørensen i Taavi Saarimäki, knjižničari Glavne uprave za knjižnice i e-izvore Europske komisije, u vrlo informativnom i zanimljivom predavanju govorili su o glavnim online servisima kao i mogućnostima pretraživanja knjižnične zbirke, katalogu Find-Er (Library and e-resources) te o dostupnim izvorima u otvorenom pristupu i alternativnim tražilicama kojima je moguće koristiti se umjesto Googleom. Posrijedi je DOAB (Direcrory of Open Acess Books), OPEN AIRE i drugih relevantnih baza u otvorenom pristupu.

O načinima naručivanja preko Bulk kataloga i općenito naručivanja preko EU-ova Bookshopa govorili su Sandrine Scheer-Peton i Dietmar Braun iz Odjela za odnose s dionicima Ureda za publikacije EU-a. Osim praktičnoga predavanja, govornici su svim sudionicima podijelili upute za naručivanje u sklopu Bulk kataloga.

Idući dan program je bio nešto kraći, ali isto tako sadržajan.

Odabrano panel-predavanje Communication campaigns of Directorate-General for Communication: InvestEU, EUandME and EUProtects održala je Carolien Peeters, voditeljica korporativnih kampanja u Glavnoj upravi za komunikacije Europske komisije. Predstavila je kampanje InvestEU, EUandME i EUProtects, uz prikazivanje kratkih filmova te je najavila daljnje aktivno- 
sti u sklopu navedenih kampanja. Uputila je sudionike na korištenje svih dostupnih materijala o kampanjama u sklopu promidžbe.

Panel-predavanje Publications for citizens vodio je Benjamin Hagard iz Odjela za informiranje građana Glavne uprave za komunikaciju Europske komisije. Predstavio je glavna izdanja Ureda za publikacije, publikacije u najavi te je skrenuo pozornost na veliki problem i izazove koji će nastati s publikacijama nakon predstojećih izbora is time povezanih promjena te izlaska Velike Britanije iz Unije.

Radionica Challenges for the European debate in the Academic community bila je namijenjena radu u skupinama, a sudionici su u grupama odgovarali na pitanja o inicijativama EU-a koje su najzastupljenije među akademskom zajednicom, a koje bi trebalo uključiti u debatu o budućnosti EU-a. S obzirom na golemu popularnost društvenih mreža i na ovoj radionici sudionici su upoznati s prednostima korištenja društvenih mreža u radu EDC-a. Dužna pozornost posvećena je i suradnicima s kojima djelatnici EDC-a ponajčešće surađuju te načinima poticanja korisnika na sudjelovanje u predstojećim izborima za Europski parlament.

Zaključno, sudjelovanjem naših predstavnika na trening seminaru otvara se mogućnost za međunarodnu suradnju, izravnu komunikaciju s Europskom komisijom, uključivanje korisnika EDC-a iz Republike Hrvatske u EU-ove programe i inicijative, širenje poslovnih kontakata za uspostavljenje individualne suradnje i suradnje institucija te razmjene ideja kao poticaj za stvaranje novih. 